\title{
Vaikų bendruomenèje
}

\section{igytos pneumonijos diagnostika}

\section{ir gydymas}

Valdonè Misevičienè

LSMU MA Vaikų ligų klinika

Reikšminiai žodžiai: vaikai, bendruomenèje igyta pneumonija, diagnostika, gydymas.

Santrauka. Straipsnyje pateikiamos naujausios vaikų bendruomenejje iggytos pneumonijos diagnostikos ir gydymo rekomendacijos, paruoštos pagal 2015 metų SAM projektą „Asmens sveikatos priežiūros kokybės gerinimas reglamentuojant rizikingiausius pacientų saugai diagnostikos ir gydymo protokolus" Nr. VP1-4.3-VRM-02-V-05-015.

Vaiku bendruomenejje igyta pneumonija (VBİP) klasikiniu atveju ìvardinama, kaip bendruomenèje igyta apatiniu kvėpavimo takų infekcija, kuri kliniškai pasireiškia plaučių parenchimos uždegimu, karščiavimu, kvẻpavimo funkcijos sutrikimu bei auskultaciniais ir (ar) rentgenologiniais plaučių pokyčiais.

VBĮP dažniausiai klasifikuojama pagal ligos eigą ir radiologinị proceso išplitimą.

Pagal ligos eigos sunkumo laipsnị VBĮP priimta skirstyti ị nesunkią (lengva/vidutinio sunkumo) ir sunkią, o pagal radiologinius požymius - $\mathfrak{i}$ alveolinę, arba skiltinę/segmentinę ir ne alveolinę, arba bronchopneumoniją (židininę).

\section{ETIOLOGIJA}

- VBĮP susergama natūralioms gyvenimo sąlygoms, kai ligą sukelia ịprasti aplinkoje cirkuliuojantys mikroorganizmai.

- Nustatyti VIVP etiologiją dažnai būna sudètinga, todèl dèl ịvairių priežasčių apie 20-60 proc. atvejų pneumonijos sukèlejjas nenustatomas.

- Streptococcus pneumonia (pneumococcus), nepaisant vakcinacijos, lieka svarbiausiu bakteriniu patogenu, sukeliančiu VBĮP bet kokio amžiaus vaikams. Lietuvoje vyrauja invaziniai $23,19,6,18$ pneumokoko serotipai.

- Jaunesniems nei penkerių metu vaikams virusai vieni arba kartu su bakterine infekcija sukelia apie 30-67 proc. visų vaikų pneumonijos atvejų.
- Atipiniai sukèlèjai (Mycoplasma pneumoniae, Chlamydophyla pneumonia) mokyklinio amžiaus vaikams randami apie 40 proc. sergančių VBĮP. Atipinès infekcijos ikimokyklinio amžiaus vaikams nèra retas reiškinys gali būti nustatomos penktadaliui šio amžiaus vaikų.

- VBĮP sukèlèjai labai priklauso nuo vaiko amžiaus (1 lentelè).

\begin{tabular}{|c|c|}
\hline Vaiko amžius & VBĮP sukèlèjai tikimybės mažèjimo tvarka \\
\hline Iki 1 mèn. & $\begin{array}{l}\text { Dažniau: B grupès streptokokas, } \\
\text { gramneigiamos žarnyno lazdelès, S. aureus } \\
\text { Rečiau: Listeria monocytogenes, CMV, } \\
\text { Chlamydia trachomatis }\end{array}$ \\
\hline 1-3 mèn. & $\begin{array}{l}\text { Dažniau: Streptococcus pneumoniae, } \\
\text { respiraciniai virusai } \\
\text { Rečiau: Chlamydia trachomatis, S. aureus, } \\
\text { Bordetella pertussis, gramneigiamos } \\
\text { žarnyno lazdelès, Streptococcus pyogenes, } \\
\text { H. Influenzae, Mycoplasma pneumoniae, } \\
\text { Chlamydophyla pneumoniae }\end{array}$ \\
\hline 3 mèn. -5 metai & $\begin{array}{l}\text { Dažniau: Streptococcus pneumoniae, } \\
\text { respiraciniai virusai, Mycoplasma } \\
\text { pneumoniae } \\
\text { Rečiau: Chlamydophyla pneumoniae, } \\
\text { Streptococcus pyogenes, H. influenzae, } \\
\text { S. aureus, Bordetella pertussis }\end{array}$ \\
\hline Daugiau kaip 5 metuc & $\begin{array}{l}\text { Dažniau: Streptococcus pneumoniae, } \\
\text { Mycoplasma pneomoniae, Chlamydophyla } \\
\text { pneumoniae } \\
\text { Rečiau: S. aureus, S. pyogenes, respiraciniai } \\
\text { virusai, H. influenzae }\end{array}$ \\
\hline
\end{tabular}




\section{RIZIKOS VEIKSNIAI}

- Neišnešioti (gimę 24-28 gestacijos savaičių) ir iki 5 metụ amžiaus vaikai.

- Lydinčiosios ịvairios lètinès ligos (kvẻpavimo organų, endokrininès, virškinimo, metabolinès, širdies ir kraujagyslių, nervų-raumenų, igimtos anomalijos ir kt.).

- Pirminis ir antrinis imunodeficitas.

- Rūkymas.

- Mitybos nepakankamumas.

- Daugiavaikių šeimų vaikai.

- Nepalankūs socialiniai ir ekonominiai veiksniai.

\section{KLINIKA}

Dažniausi vaikų pneumonijos klinikiniai simptomai:

- Ümi pradžia, dažnai po ūminès viršutinių kvėpavimo takų infekcijos.

- Karščiavimas.

- Padidejęs kvépavimo dažnis - tachipnejja.

- Kosulys.

- Kiti kvėpavimo funkcijos sutrikimo požymiai (2 lentelè).

- Krūtinès ląstos, pilvo, galvos skausmas.

- Intoksikacija ir kiti bendrieji negalavimo simptomai.

- Ivairūs auskultaciniai plaučių pokyčiai neretai atsiranda vèliau, 2-3 sirgimo parą: smulkūs drègni ir (ar) sausi karkalai, pakitusio alsavimo ir perkusinio bei auskultacinio garso asimetriškumas.

- Iki 50 proc. atipinès ir virusinès etiologijos VBĮP lydi bronchų obstrukcijos sindromas.

- Vaiko būklè gali būti nuo lengvos iki gyvybei pavojingos (3 lentelè).

- Atipinès infekcijos sukeltai pneumonijai dažniau būdinga palaipsnè ir lengvesnè ligos eiga.

VBĮP gali komplikuotis ne tik įvairiais plaučių, bet ir kitu organu pažeidimais, taip pat sisteminiu uždegimo atsaku i infekciją. Dažniausios komplikacijos - parapneumoninis pleuritas ar empiema bei plaučio abscesas ir nekrotizuojanti pneumonija.

\section{DIAGNOSTIKA}

- Vaikams bakterinès etiologijos pneumonija tikètina, kai yra karščiavimas virš $38,5^{\circ} \mathrm{C}$ ir kvejpavimo funkcijos sutrikimo požymiai bei tachipnèja, išliekanti nukritus temperatūrai (pav.).

- PSO rekomendacijose tachipnejja nurodoma kaip svarbus pneumonijos požymis, kai radiologinè diagnostika yra negalima.

- Dauguma svarbių VBĮP klinikinių požymių (kosulys, auskultaciniai ir radiologiniai plaučių pokyčiai) gali atsirasti vèliau arba visai neatsirasti, todèl jų vertė ankstyvai ligos diagnostikai nedidelè.

- Vyresniems vaikams kvejpavimo funkcijos sutrikimo požymiai yra diagnostiškai svarbesni už ankstyvus plaučių auskultacijos ar perkusijos duomenis.

- Jei karščiuojantis ikimokyklinio amžiaus vaikas dūsta, švokščia, pirminẻ bakterinè pneumonija mažai tikètina.
2 lentelè. Vaiku kvèpavimo sutrikimu vertinimas

\begin{tabular}{|c|c|}
\hline $\begin{array}{l}\text { Tachipnèja } \\
\text { (kvėpavimo dažnis, } \\
\text { k./min.) }\end{array}$ & iki 2 mèn. $>60$ \\
\hline $\begin{array}{l}\text { Kiti kvėpavimo } \\
\text { funkcijos sutrikimo } \\
\text { požymiai }\end{array}$ & $\begin{array}{l}\text { Pasunkèjęs alsavimas } \\
\text { Nosies sparnelių ir kitų pagalbinių raumenų } \\
\text { darbas } \\
\text { Dusulys, mažiems vaikams - švokštimas } \\
\text { Nesinchroninis kvėpavimo pobūdis } \\
\text { Dejavimas, stenèjimas } \\
\text { Pakitusi sąmonès būklè } \\
\text { Pakitusi odos ir gleivinių spalva }\end{array}$ \\
\hline $\begin{array}{l}\text { Ūminio kvėpavimo } \\
\text { nepakankamumo } \\
\text { kriterijai }\end{array}$ & $\begin{array}{l}\mathrm{SpO}_{2}<92 \text { proc. ir (ar) } \\
\mathrm{PaO}_{2}<60 \mathrm{mmHg}, \mathrm{PaCO}_{2}>50 \mathrm{mmHg} \text { ir } \\
\mathrm{pH}<7,3\end{array}$ \\
\hline
\end{tabular}

3 lentelè. Plaučių uždegimu sergančio vaiko klinikinès būklès sunkumo jvertinimas

\begin{tabular}{|c|c|c|}
\hline Vaiko amžius & Nesunki & Sunki \\
\hline $\begin{array}{l}\text { Kūdikis ir } \\
\text { mažas vaikas } \\
(<5 \mathrm{~m} .)\end{array}$ & $\begin{array}{l}\text { Temperatūra } \\
<38,5^{\circ} \mathrm{C} \\
\mathrm{KD}<50 \mathrm{k} . / \mathrm{min} . \\
\text { Lengvas } \\
\text { kvėpavimo } \\
\text { funkcijos } \\
\text { sutrikimas }\left(\mathrm{SpO}_{2}\right. \\
>92 \text { proc.) } \\
\text { Valgo ir geria } \\
\text { gerai }\end{array}$ & $\begin{array}{l}\text { Temperatūra }>38,5^{\circ} \mathrm{C} \\
\mathrm{KD}>70 \mathrm{k} . / \mathrm{min} . \\
\text { Vidutinis ar sunkus kvėpavimo } \\
\text { funkcijos sutrikimas }\left(\mathrm{SpO}_{2}\right. \\
<92 \text { proc. ir (ar) kraujo dujų } \\
\text { pokyčiai) } \\
\text { Nenuolatinè apnèja } \\
\text { Atsisako valgyti } \\
\text { Dehidratacija } \\
\mathrm{KPL}>2 \text { sek. }\end{array}$ \\
\hline $\begin{array}{l}\text { Vyresnis } \\
\text { vaikas } \\
(\geq 5 \mathrm{~m} .)\end{array}$ & $\begin{array}{l}\text { Temperatūra } \\
<38,5^{\circ} \mathrm{C} \\
\mathrm{KD}<50 \mathrm{k} . / \mathrm{min} . \\
\text { Lengvas } \\
\text { kvėpavimo } \\
\text { funkcijos } \\
\text { sutrikimas }\left(\mathrm{SpO}_{2}\right. \\
>92 \text { proc.) } \\
\text { Valgo ir geria } \\
\text { gerai }\end{array}$ & $\begin{array}{l}\text { Temperatūra } \geq 38,5^{\circ} \mathrm{C} \\
\mathrm{KD}>50 \mathrm{k} . / \mathrm{min} . \\
\text { Sunkus kvėpavimo funkcijos } \\
\text { sutrikimas }\left(\mathrm{SpO}_{2}<92 \text { proc. ir }\right. \\
\text { (ar) kraujo duju pokyčiai) } \\
\text { Intoksikacija } \\
\text { Dehidratacija } \\
\mathrm{KPL}>2 \text { sek. }\end{array}$ \\
\hline
\end{tabular}

- Tyrimai turi būti atliekami tikslingai, jau įtariant VBĮP ir surinkus anamnezès duomenis, ivvertinus klinikinius požymius ir paciento būklę.

- Kiekvienam vaikui, sergančiam plaučiuc uždegimu, reikètuc atlikti pulsoksimetriją, o stacionare - ir kraujo dujų tyrimą, jei $\mathrm{SpO}_{2}<92$ proc.

- BKT ir CRB dažniausiai nepadeda atskirti virusinès, bakterinès ar mišrios etiologijos plaučių uždegimo.

- Prokalcitonino koncentracijos tyrimas - nèra rutininis tyrimas, tačiau gali būti atliekamas, ịtarus pneumoniją ir sepsit.

- Ligos sukèlèjas nustatomas iš kraujo, skreplių ar bronchų nuoplovų pasèlių, taip pat ištyrus nosiaryklès sekretą ir (ar) nuoplovas iš nosiaryklès polimerazès grandininès reakcijos metodu (PGR) virusų bei bakterijų DNR / RNR nustatymui.

- Jei atliekama pleuros punkcija - tiriamas pleuros skystis.

- Jei ittariama mikoplazmos sukelta pneumonija, dažniausiai atliekami serologiniai kraujo tyrimai, kurie reikšmingi tik vèlyvai diagnostikai, kai tiriami poriniai serumai, todèl nèra plačiai rekomenduojami.

- Patikimų tyrimo metodų, patvirtinančių C. pneumonia sukeltą infekciją, šiuo metu nèra. 
Tęstinè ir kartotinè temperatūra $>38,5^{\circ} \mathrm{C}$

Tachipnèja \pm

Kiti kvejpavimo funkcijos sutrikimo požymiai \pm

Kiti būdingi VBItP klinikiniai simptomai

Panašu i kitą priežastį?

1) Amžius $<5$ m.

2) Yra dusulys, švokštimas

3) Yra ŪVRI ar kiti nebūdingi požymiai

\begin{tabular}{|l|}
\hline \multicolumn{1}{|c|}{ Taip } \\
\hline Bronchiolitas? \\
Bronchitas? \\
Kita liga? \\
\hline
\end{tabular}

İtariama VBItP

Taip

2) Krūtinès ląstos Ro

3) Laboratoriniai tyrimai pagal poreikị

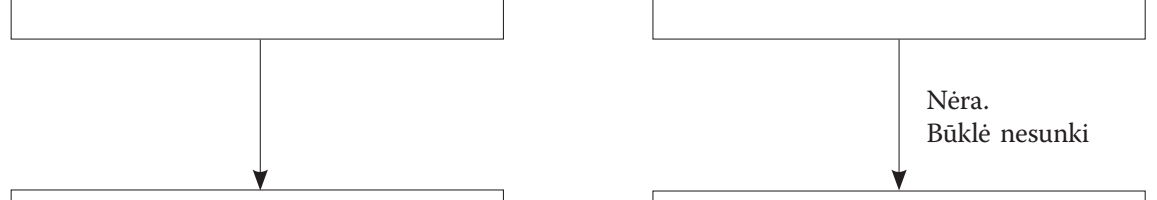

1) Diagnozuoti VBItP

2) Ambulatorinis gydymas

3) Geriamieji antibiotikai pagal

emperinès antibiotikoterapijos protokolą

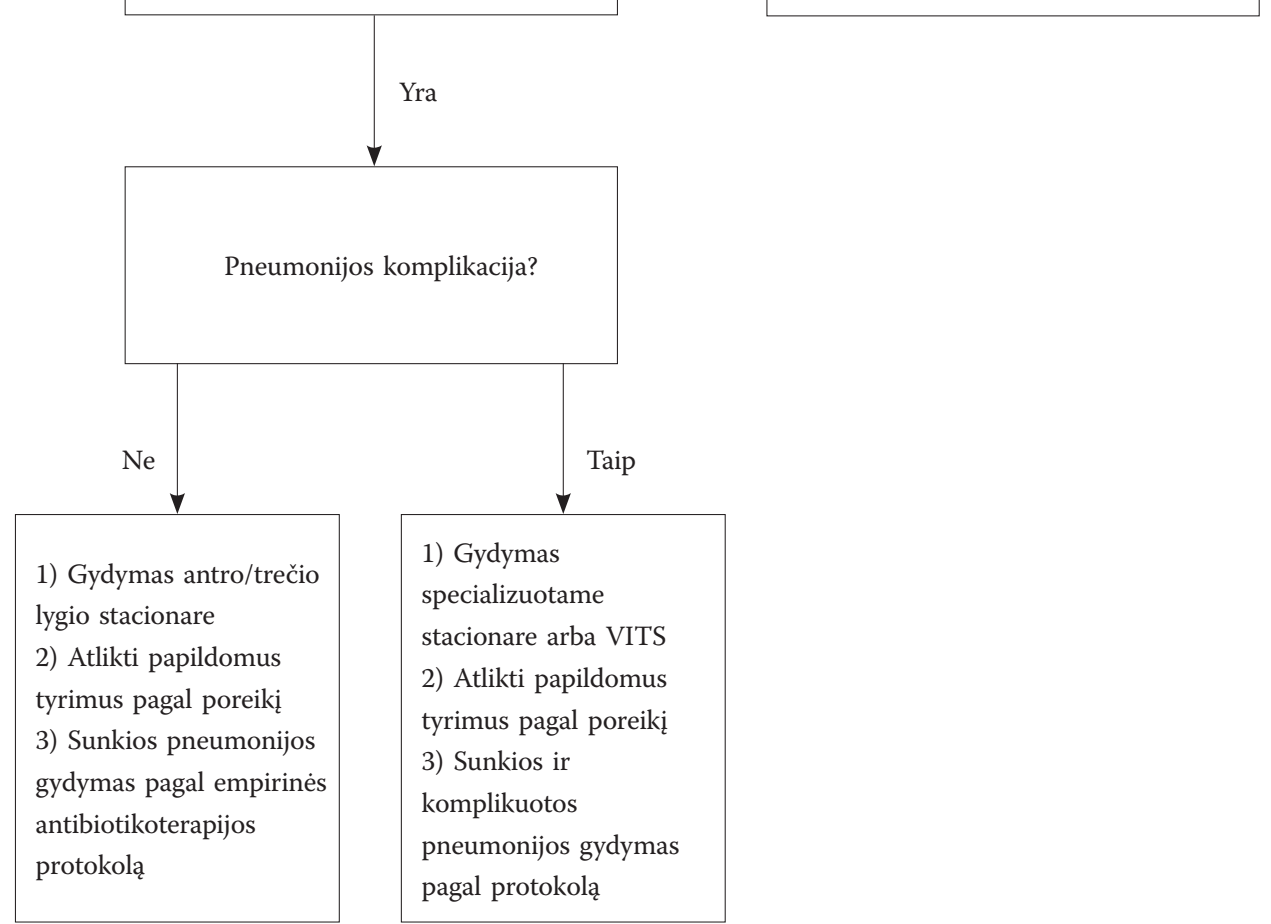

Pav. Vaiku bendruomeneje igytos pneumonijos diagnostikos algoritmas 
- Pirmos eilès radiologinis tyrimo metodas yra rentgenografija.

- Vaikams, kuriems kliniškai diagnozuojama nesunkios eigos VBĮP, krūtinès ląstos rentgenogramos atlikti nereikia.

- Radiologinei VBİP diagnostikai būdinga klinikinių simptomų bei radiologiniu pakitimų disociacija: pakitimai gali atsirasti ir (ar) išnykti vèliau nei klinikiniai simptomai.

- Priekinèje krūtinès ląstos rentgenogramoje būdinga plaučiu parenchimos infiltracija, kuri gali apimti vieną ar kelias plaučio skiltis (skiltinè pneumonija), vieną ar kelis skilties segmentus (segmentinè pneumonija) ar pasireikšti peribronchine infiltracija ir smulkiais infiltracijos židiniais (bronchopneumonija).

- Pneumonijos atveju plaučių rentgenologiniai pakitimai nèra specifiški sukèlèjui.

- Kontrolinė krūtinès ląstos rentgenograma neatliekama, jei vaikas visiškai pasveiko, tačiau, kai pneumonija komplikuota atelektaze, audinio destrukcija, pleuritu ar yra besitęsiantys ligos simptomai, rekomenduojama tyrimą kartoti.

- Ultragarsinis tyrimas - dažniausiai atliekamas norint ivvertinti skysčio kiekị ir pobūdị pleuros ertmèje bei nustatyti pleuros punkcijos vietą.

- Kompiuterinè krūtinès ląstos tomografija atliekama tik sunkios ir komplikuotos pneumonijos atveju diferenciacijos tikslu.

- Bronchoskopinis tyrimas - dažniausiai atliekamas diferencinès diagnostikos, kartais gydymo tikslu, siekiant patikslinti pneumonijos priežastị, ịvertinti kvejpavimo takų būklę, pašalinti gleivių kamščius, svetimkūnius, paimti pasèlị ir kt. Procedūra turi būti atliekama patyrusio specialisto, sukèlus bendrąją nejautrą, VITS III lygio stacionare.

- Tuberkulino méginys atliekamas, jei įtariama TB infekcija diferenciacijos tikslu.

\section{DIFERENCINÉ DIAGNOSTIKA}

- Vaikams iki 2 metų VBĮP dažniausiai reikia atskirti nuo bronchiolito, vyresniems - nuo aspiracinès pneumonijos, neinfekcinių priežasčių, galinčių imituoti pneumoniją, tuberkuliozès.

- Jei pneumonija kartojasi, būtinas išsamus pulmonologinis ištyrimas dèl lètinių plaučių ligų, igimtų sklaidos defektų, imunodeficito ir kt.

\section{GYDYMAS}

- Gydymas turi būti individualus, kompleksinis ir etapinis pagal poreiki - ambulatorinis, stacionarinis, intensyvios terapijos skyrius, reabilitacinis.

- Dauguma vaikų, sergančiuc pneumonija, gali būti saugiai ir efektyviai gydomi namuose geriamaisiais antibiotikais.

\section{Pagrindinès gydymo rekomendacijos:}

- Režimas - apribotas fizinis aktyvumas.

- Dieta fiziologiškai normali, skiriant gerti papildomai skysčių.

- Oksigenoterapija, esant poreikiui.
- Skysčiu terapija, esant poreikiui.

- Temperatūros, skausmo valdymas, kitas simptominis gydymas.

- Etiologinis gydymas:

$\checkmark$ Empirinis antibakterinis gydymas pagal ittariamą sukèlèją. Vèliau galima korekcija pagal patikslintą patogeną ir jo jautrumą antibiotikams.

$\checkmark$ Antivirusinis gydymas - įtariant gripą ar kitą virusinę infekciją, kurią galima gydyti etiologiškai.

- Plaučių drenažinès funkcijos gerinimas (vibracinis masažas, kt.) taikomas tik nekarščiuojančiam vaikui, tačiau rutiniškai nerekomenduojamas.

- Minimalus manipuliacijų skaičius mažina sergančio vaiko metabolinius ir $\mathrm{O}_{2}$ poreikius.

- Invaziniai gydymo metodai taikomi komplikuotu VBIP atvejais, kai reikalinga pleuros ar absceso punkcija, drenažas, torokoskopija ir (ar) patologinio proceso sanacija chirurginiu ir (ar) kitu invaziniu būdu.

\section{Gydymo stacionare indikacijos:}

- Itariama bakterinè pneumonija kūdikiui (iki 12 mèn.).

- $\mathrm{SpO}_{2} \leq 92$ proc., cianozè.

- Kvėpavimo dažnis $>70$ k./min. (kūdikiams ir vaikams iki $2 \mathrm{~m}$.$) .$

- Kvėpavimo dažnis $>50 \mathrm{k} . / \mathrm{min}$. (vyresniems vaikams).

- Pasunkèjęs alsavimas (stenèjimas, dejavimas, švokštimas, kt.).

- Apnejjos epizodai.

- Atsisakymas valgyti, dehidratacijos, blogos perfuzijos požymiai.

- Ittariant skysti pleuros ertmèje.

- Ittariant aspiracinę ar stafilokokinę pneumoniją.

- Jei nèra teigiamo efekto po 48 val. nuo antibakterinio gydymo pradžios.

- Esant nepalankioms buitinèms ir socialinėms sąlygoms.

\section{Indikacijos vaikus gydyti intensyviosios terapijos} skyriuje (VITS):

- $\mathrm{SpO}_{2}<92$ proc., tiekiant drékintą deguoni pro kaukę, kai $\mathrm{FiO}_{2}>0,5$ (tiekiant $\mathrm{O}_{2}$ kauke be rezervuaro $>8 \mathrm{l} / \mathrm{min}$. srove).

- Šoko požymiai, tachikardija, šaltas lipnus prakaitas, sąmonès sutrikimas.

- Pasikartojantys apnejjos epizodai arba nereguliarus kvėpavimas.

- Didejantis KD ir ŠSD, esant klinikiniams kvėpavimo funkcijos sutrikimo požymiams be hiperkapnijos ar su hiperkapnija $\left(\mathrm{PaCO}_{2}>50 \mathrm{mmHg}\right)$.

\section{Indikacijos taikyti reabilitacija:}

- Po ambulatoriškai ar stacionare taikyto aktyvaus ir pirmo etapo reabilitacinio gydymo, pacientas gali būti siunčiamas sveikatą grąžinančio gydymo arba antro bei trečio etapo medicininès reabilitacijos ị pulmonologinio profilio reabilitacijos ịstaigą.

\section{Pagrindinés antibakterinio gydymo rekomendacijos:}

- Vaikai, kuriems plaučiu uždegimas diagnozuojamas kliniškai, turi būti gydomi antibiotikais pagal empirinès terapijos rekomendacijas (4 lentelè), nes nèra nè vieno 
4 lentelè. VBĮP empirinio antimikrobinio gydymo rekomendacijos

\begin{tabular}{|c|c|c|}
\hline Gydymas Ligos eiga & Nesunki pneumonija & Sunki \\
\hline Pirmos eilès antibiotikas & $\begin{array}{l}\text { Amoksicilinas geriamasis } \\
\text { Makrolidas (dažniausiai klaritromicinas) } \\
\text { geriamasis - tik esant aiškiems atipinės } \\
\text { infekcijos požymiams }\end{array}$ & Benzilpenicilinas ị veną \\
\hline $\begin{array}{l}\text { Nèra atsako ì pirmos eilès } \\
\text { antibiotiką per pirmas } \\
48 \text { val. } \\
\text { ARBA } \\
\text { ittariama mišri infekcija, } \\
\text { atsparumas siauro spektro } \\
\text { penicilinams, } \\
\text { nuo pat pradžiu ligos eiga } \\
\text { sunki ir komplikuota }\end{array}$ & $\begin{array}{l}\text { Amoksicilinas su klavulano rūgštimi } \\
\text { geriamasis } \\
\text { ARBA } \\
\text { Ampicilinas su sulbaktamu geriamasis } \\
\text { ARBA } \\
\text { II kartos cefalosporinas (cefuroksimas) } \\
\text { geriamasis }\end{array}$ & $\begin{array}{l}\text { Benzilpenicilinas ị veną + makrolidas geriamasis ar ị veną } \\
\text { ARBA } \\
\text { Amoksicilinas su klavulano rūgštimi i veną } \\
\pm \text { makrolidas geriamasis ar } \mathfrak{i} \text { veną } \\
\text { ARBA } \\
\text { Ampicilinas su sulbaktamu } \mathfrak{i} \text { veną } \\
\pm \text { makrolidas geriamasis ar } \mathfrak{i} \text { veną } \\
\text { ARBA } \\
\text { III kartos cefalosporinas (cefotaksimas, ceftriaksonas) } \mathfrak{i} \text { veną } \\
\pm \text { makrolidas geriamasis ar } \mathfrak{i} \text { veną }\end{array}$ \\
\hline Alergija penicilinams & $\begin{array}{l}\text { Makrolidas (dažniausiai klaritromicinas) } \\
\text { geriamasis, jei nustatyta pirmo tipo } \\
\text { alerginė reakcija penicilinams } \\
\text { ARBA } \\
\text { II kartos cefalosporinas geriamasis, jei } \\
\text { nustatyta ne I tipo alerginė reakcija } \\
\text { penicilinams }\end{array}$ & $\begin{array}{l}\text { Jei nustatyta ne I tipo alerginè reakcija penicilinams, II, III kartos } \\
\text { cefalosporinas ị veną } \\
\pm \text { makrolidas geriamasis ar i̇ veną } \\
\text { Jei nustatyta I tipo alerginè reakcija penicilinams, vankomicinas i̇ veną } \\
\pm \text { makrolidas geriamasis ar } \mathfrak{i} \text { veną } \\
\text { ARBA } \\
\text { Chinolonai ị veną }\end{array}$ \\
\hline
\end{tabular}

klinikinio požymio, padedančio patikimai atskirti virusinę ar kitokią pneumonijos etiologiją. Nustačius sukẻlèją, gydymas koreguojamas pagal mikrobiologinio pasèlio rezultatus.

- Antibiotikai ị veną turètų būti skiriami, jei vaikas negeria ar nepasisavina geriamuju antibiotikų arba jam iš karto nustatoma sunki, komplikuota ligos eiga, vaikas gydomas stacionare. Akivaizdžiai pagerejjus būklei, bet ne anksčiau kaip po $48-72$ val. kritus temperatūrai, toliau galima skirti geriamuosius antibiotikus.

- Jei 48-72 val. efekto ì paskirtą gydymą nèra, ar po kelių dienų pertraukos vaikas kartotinai sukarščiuoja, būtina iš naujo įvertinti būklę, galimas komplikacijas ir koreguoti gydymą.

- Amoksicilinas yra pirmos eilès antibiotikas įvairaus amžiaus vaikų, sergančių pneumonija, ambulatoriniam gydymui.

- Lietuvoje benzilpenicilinas ị veną yra pirmos eilès vaistas ịvairaus amžiaus vaikų pneumonijos gydymui stacionare.

- Makrolidai monoterapija skiriami tik nuo atipinès infekcijos arba esant alergijai penicilinui bei kitiems beta laktaminiams antibiotikams.

- Jei ittariama mišri infekcija, arba yra nepakankamas efektas i beta laktaminius antibiotikus, galimi pastaruju ir makrolidų deriniai bet kurio amžiaus vaikams.

- Jei pneumonija yra susijusi su gripo virusu, tikètina antrinè S. pneumoniae ar S. aureus sukelta infekcija, todèl empiriniam gydymui antibiotikais rekomenduojamas amoksicilinas su klavulano rūgštimi arba ampicilinas su sulbaktumu.

- Naujagimiai gydomi tik ligoninejje, empiriškai rekomenduotina skirti benzilpeniciliną $\mathfrak{i}$ veną + gentamiciną $\mathfrak{i}$ veną.

- Nesunki VBĮP gydoma bent 3 dienas po temperatūros sumažejimo, bet ne mažiau kaip 5 d., atipinè pneumonija - iki 2-3 sav., sunki VBĮP - ne mažiau kaip 2-3 sav.

\section{CHILDREN WITH COMMUNITY ACQUIRED PNEUMONIA DIAGNOSIS AND TREATMENT}

\section{VALDONË MISEVIČIENÉ \\ DEPARTMANET OF CHILDREN DISEASES LITHUANIAN UNIVERSITY OF HEALTH SCIENCES}

Keywords: children, community acquired pneumonia, diagnosis, treatment. Summary. Recommendations for diagnosis and treatment of community acquired pneumonia (CAP) in children are presented in the article. The article is prepared on the basis of the protocol "Diagnosis and management of CAP in children" ordered by The Ministry of Health of The Republic of Lithuania in 2015.

\section{LITERATŪRA}

1. A. Valiulis, V. Misevičienè, E. Vaitkaitienè, V. Radžiūnienè. Vaiku visuomenėje igytos pneumonijos diagnostika ir gydymas. SAM diagnostikos ir gydymo protokolai: "Asmens sveikatos priežiūros kokybès gerinimas reglamentuojant rizikingiausius pacientu saugai diagnostikos ir gydymo protokolus" Nr. VP1-4.3-VRM-02-V-05-015, Vilnius, 2015. Prieiga per interneta: https://sam.Irv.lt/diagnostikos-gydymo-metodikos-ir-rekomendacijos/diagnostikos-ir-gydymo-protokolai

2. Harris M, Clark J, Coote N, Fletcher P, Harnden A, McKean M, Thomson A, British Thoracic Society Standards of Care Committee: British Thoracic Society guidelines for the management of community acquired pneumonia in children: update 2011.Thorax 2011; 66 Suppl 2: ii1-23.

3. Bradley JS, Byington $\mathrm{CL}$, Shah SS, et al. The management of community-acquired pneumonia in infants and children older than 3 months of age: clinical practice guidelines by the Pediatric Infectious Diseases Society and the Infectious Diseases Society of America. Clin Infect Dis 2011; 53: e25-76.

4. Esposito S, Patria M, Tagliabue C, et al. CAP in children. European Respiratory Monograph 2014; 63: 130-39.

5. Principi $\mathrm{N}$, Esposito S. Management of severe community-acquired pneumonia of children in developing and developed countries. Thorax 2011; 66: 815-22.

6. Bowen SJ, Thomson AH. British Thoracic Society paediatric pneumonia audit: a review of 3 years of data. Thorax 2013; 68: 682-83.

7. Esposito S, Cohen R, Domingo JD, et al. Antibiotic therapy for pediatric community-acquired pneumonia: do we know when, what and for how long to treat? Pediatr Infect Dis J 2012; 31: e7885.

8. World Health Organization. Pneumonia. Fact sheet No. 331.2011. Prieiga per internetą www.who.int/mediacentre/factsheets/fs331/en

9. Mulholland S, Gavranich JB, Gillies MB, Chang AB. Antibiotics for community-acquired lower respiratory tract infections secondary to Mycoplasma pneumoniae in children. Cochrane Database Sys Rev 2012; 9: CD004875. 